\title{
Benefits and Challenges of Telework During The Covid-19 Pandemic
}

\author{
Susanti Saragih, Santy Setiawan, Teddy Markus, Peter Rhian \\ Universitas Kristen Maranatha, Indonesia \\ Jl. Surya Sumantri No.65, Sukawarna, Kec. Sukajadi, Kota Bandung, Jawa Barat 40164
}

\section{ARTICLE INFO}

Keywords:

Telework

Remote work

Work from home

Covid-19 Pandemic

HR Policy

\section{Kata Kunci:}

Pekerjaan jarak jauh

Kerja jarak jauh

Bekerja dari rumah

Pandemi Covid-19

Kebijakan SDM

\section{A B S T R A C T}

During the Covid-19 pandemic, the term work from home (WFH) has been introduced to refer to a work arrangement in which individual can complete their duties while they are at home. While most flexible work arrangements are a preference, work from home is mandatory. Therefore, the impact of WFH during the Covid-19 pandemic needs to be studied. The total respondent of this study is 337 employees, who are works at home during the pandemic. The results showed that the three main benefits employees might gain during WFH are flexibility, more time with family, and less travel time. On the other side, employees struggle to balance their personal and work life, access to websites or software, and limited devices and workspace. Most of the companies are not ready for the WFH scheme though some of them gave support to employees (e.g., quota subsidy). This research gave some essential suggestions for HR managers in designing remote work for the future.

\section{SARI PATI}

Selama masa pandemic Covid-19, istilah work from home (WFH) mulai diperkenalkan untuk merujuk pada bentuk pengaturan kerja fleksibel di mana individu dapat menyelesaikan tugasnya selama berada di rumah. Sementara sebagian besar bentuk kerja flexible adalah preferensi, WFH bersifat wajib. Oleh karena itu, dampak WFH di masa pandemi Covid-19 perlu dikaji. Jumlah responden penelitian ini adalah 337 karyawan, yang bekerja di rumah selama pandemi. Hasil penelitian menunjukkan bahwa tiga manfaat utama yang diperoleh karyawan selama WFH adalah fleksibilitas, lebih banyak waktu bersama keluarga, dan lebih sedikit waktu untuk perjalanan. Di sisi lain, karyawan berjuang untuk menyeimbangkan kehidupan pribadi dan pekerjaan mereka, akses ke situs web atau perangkat lunak, dan perangkat dan ruang kerja yang tidak memadai. Walaupun sebagian besar perusahaan belum siap dengan skema WFH tetapi beberapa dari mereka memberikan dukungan kepada karyawan. Penelitian ini memberikan beberapa saran penting bagi manajer SDM dalam merancang kerja jarak jauh untuk masa depan.

(c) 2021 IRJBS, All rights reserved. susanti.saragih@eco.maranatha.edu 


\section{INTRODUCTION}

Remote work has grown since the early 1990s' but it hasn't worked successfully due to many organizations still reluctance to adopt remote working and the diffusion has remained below expectations. Moreover, the business demands and scheduling that still requires employees to work from the office and visit client on-site regularly. Managers are concerned about the monitoring of performance in remote working and working conditions. Perez et al. (2005) also stated that the adoption of remote work is also influenced by organizational's resources (e.g. human resources, technological resources, and organizational resources). Therefore, despite recent advances in technology and information, remote work has not been a preference for employees and organizations.

However, the Covid-19 has coerced organizations to replace traditional face-to-face work with remote work. This scheme is known as work from home (WFH). Most workers had little experience in remote working, nor were the organization. All of a sudden, remote working has become the new normal. Employees faced many obstacles of balancing work and family demands in general, adjusting to a new way of working. Many recent studies have found that during WFH, the employee feels boredom, anxiety, isolated and stress (Adisa et al., 2020; Banerjee and Rai, 2020; Wang et al., 2020; Williams et al., 2020). Aropah, Sarma \& Sumertajaya (2020) found that employee performance during WFH is more likely depend on leadership and work environment.

This article investigates employee experiences during $\mathrm{WFH}$, for instance, the main barriers and advantages of WFH, ways to stay motivated to work during WFH, and employees' perception of organizational readiness in applying the WFH scheme. This research is vital so that managers explore ways to help workers deal effectively with the challenges during WFH and update the policy of remote work for the future after the Covid-19 Pandemic.

\section{Literature Review}

Working remotely is a form of flexible work arrangement (FWA). It has defined as policies and practices that apply formally in an organization and allow people to modify when and where the work is carried out (Maxwell et al., 2006, p. 138). There is an increasing number of flexible work arrangements on offer across organizations. They are flexible hours of work, casual dress day, mealtime flextime, break arrangement, compressed working weeks, telecommuting, part-time work, and job sharing (SHRM, 2015). These flexible work arrangements allow individuals to modify aspects of work, for instance, the timing of work, the place, and the way they conduct the task. Wang et al. (2020) found that telecommuting, which involves working from home using technology, has been instrumental in helping employees meet the many demands on their time. Therefore, flexible work arrangement has become a means to retain staff and to attract groups who are currently under-represented in employment due to family responsibilities or other limitations (Kropf, 1999).

According to the 2015 SHRM research, FWAs refer to employers and employees as a vital antecedent of job satisfaction. More than one-half of respondents (56\%) of employees who participated in the research cited flexibility to balance work and life issues as a critical aspect of their job satisfaction. Then, HR professionals stated that giving various FWAs leads to employee excellence, higher commitment (74\%), employee productivity (67\%), and quality of employees' work (59\%). Besides, FWAs have also had a positive impact on various business aspects, including retaining employees (75\%), attracting employees (61\%), and turnover (52\%).

\section{METHODS}

\section{Participants}

To investigate how employee experience works from home during the Covid-19 pandemic, we constructed open and close questions based on the topic we studied. The respondents were selected based on the criteria, namely employees who are 
working full time and doing work from home during the pandemic. The questionnaires were distributed online through social media, mailing lists, and chat groups. A total of 337 employees returned the complete surveys. In order to maximize the likelihood that the employees would respond to the survey, we provide door prizes that were given to some respondents randomly. The descriptive statistic of the respondents is shown in Table 1.

The set of open questions has been set to describe employee perception and experience during work from home (See Table 2). The answers are grouped into several categories that can describe the situation during $\mathrm{WFH}$.

In part three of the questionnaire, the respondents were asked to evaluate their organization policy and their satisfaction level during WFH. Table 3 shows all the results.

\section{RESULTS AND DISCUSSION The pros of WFH}

In this study, we asked the respondents what the main benefits of WFH they had experience. Flexibility, more time with family, and time saved with less commuting have become the highest categories. Work flexibility is the ability of workers to change work location, change work hours, when, how, and how long the work is done (Shwab, 2016). Work flexibility accommodates employees to balance job demands and resources to address their personal and family needs and preferences (Autor, 2019). During WFH, the employee may start to work earlier or finish later based on individual needs, such as family responsibilities. Work flexibility during WFH may also include employee's ability to organize their tasks without the manager having to check on progress regularly. Therefore, this flexibility has become the benefit of WFH during Covid-19 Pandemic.

Table 1. Respondent Profile

\begin{tabular}{llc}
\hline Variable & Category & Percentage \\
\hline Gender & Male & $39 \%$ \\
& Female & $61 \%$ \\
Age & $>21-30$ years old & $28 \%$ \\
& $>31-40$ years old & $44 \%$ \\
& $>41-50$ years old & $17 \%$ \\
& $>51$ years old & $10 \%$ \\
Marital Status & Married & $67 \%$ \\
& Single & $33 \%$ \\
Living Arrangement & Living with spouse only & $45 \%$ \\
Using technology during WFH & Living with children & $55 \%$ \\
Internet Quota Subsidy from Organization & Yes (Full) & $96 \%$ \\
& Yes (Partial) & $4 \%$ \\
\hline
\end{tabular}


Table 2. Perception about WFH

\begin{tabular}{|c|c|c|}
\hline Item & Category & Percentage \\
\hline \multirow[t]{4}{*}{ Benefits of WFH } & Flexibility & $69.1 \%$ \\
\hline & More time with family & $60.5 \%$ \\
\hline & Time saved with less commuting & $50.1 \%$ \\
\hline & Freedom (e.q. casual clothes) & $32.6 \%$ \\
\hline Disadvantages of Working from & Lack of engagement with colleagues and supervisor & $51 \%$ \\
\hline \multirow[t]{4}{*}{ Home } & Feeling isolated & $39.2 \%$ \\
\hline & Lower pay & $48.1 \%$ \\
\hline & Potential burnout (health problems) & $32 \%$ \\
\hline & Home distractions & $30 \%$ \\
\hline \multirow[t]{5}{*}{ The main challenges of WFH } & Blurred boundaries between home and work & $53.1 \%$ \\
\hline & $\begin{array}{l}\text { Workers not having access to Software or adequate } \\
\text { devices }\end{array}$ & $45.4 \%$ \\
\hline & Issues with teamwork or supervisor & $44.5 \%$ \\
\hline & Physical discomfort to work at home & $43.6 \%$ \\
\hline & Longer work hours & $45.7 \%$ \\
\hline \multirow[t]{5}{*}{ Ways to stay motivated during WFH } & Check in with colleagues & $77.1 \%$ \\
\hline & Create a working environment at home & $52.8 \%$ \\
\hline & Organize the schedule & $50.7 \%$ \\
\hline & Keep informed on the work progress & $17.5 \%$ \\
\hline & Focus on the main tasks & $20.5 \%$ \\
\hline \multirow{4}{*}{$\begin{array}{l}\text { In my opinion, traits you need to be } \\
\text { productive and successfully work } \\
\text { from home. }\end{array}$} & Highly committed & $86.6 \%$ \\
\hline & Responsible & $89.3 \%$ \\
\hline & Flexible & $68.8 \%$ \\
\hline & Good time management & $46.9 \%$ \\
\hline
\end{tabular}

Table 3. Perception about WFH

\begin{tabular}{llc}
\hline Item & Category & Percentage \\
\hline Organization readiness to apply WFH policy & Yes & $26.7 \%$ \\
& No & $73.3 \%$ \\
\hline I received moral support from organization during WFH & Yes & $86.9 \%$ \\
& No & $13.1 \%$ \\
\hline Overall, I satisfied with my performance during WFH & Yes & $59.3 \%$ \\
& No & $40.7 \%$ \\
In the future, I would rather work from home & Yes & $48.7 \%$ \\
& No & $51.3 \%$ \\
\hline
\end{tabular}


Surveys showed that during the pandemic, employees are also experiencing a positive feeling. The employee who has to work from the office tends to work in fear and anxiety of getting infected. Therefore, the employee feels safe to work at home because they will have more time with family and focus on family health. Moreover, WFH has eliminated the daily commute to and from work, which could save a significant amount of time commuting. Alexander et al., (2020) stated that this could have an economic consequence (e.q. on transportation, gasoline) and employees' health (e.q. less commuter stress).

\section{The cons of WFH}

Table 2 showed us that employees who experience WFH perceived that there are three main disadvantages of WFH. Firstly, lack of engagement with colleagues and supervisors, feeling isolated and feeling insecure because of lower pay. During WFH in the pandemic situation, the employee relies heavily on electronic communication to foster collaboration and productivity. However there is a shred of evidence that people who work remotely have more problems than face-to-face communication situations (McKinsey, 2021). They feel a few interactions, lack non-verbal clues, and become a trigger for loneliness and isolation (Kniffin et al., 2021). Moreover, during the WFH scheme, the employee might experience grieve because of the loss of family members or friends. The Covid-19 pandemic also coerces the company to do mass layoffs or wage cuts because of the unprecedented global economic crisis. ome of the respondents in this study (48.1\%) reported that the pandemic impacted their wages.

\section{The main challenge of WFH}

During the pandemic, employee who is working parents, the school closed, and the closing of other care facilities have made working from home challenging. This study revealed that a blurred boundary between home and work becomes the main challenge of WFH. There are $55 \%$ of the respondents reported that they are living with children. Those who have care responsibilities (e.q. parents with school-aged children) found that it's hard to focus on work during work hours because they have to provide care to parents or children at the same time (Eurofound, 2020). The situation became worse if employees don't have personal space to work at home, access to software. They have to utilize their own space, devices, and equipment to help them work properly at home. $43,6 \%$ respondents (Table 1) also reported that they feel physical discomfort to work at home. Some studies found that WFH causing more back and neck pain, sleeping disorder, eye-sight problem, obesity, stress and fatigue (ILO, 2020).

Table 2 also reported that there are some of the steps that employee has took to stay motivated during WFH.

1. Check in with colleagues. They tried to keep in touch with friends and families through video call and message. This help them to get socialize and connected.

2. Create a working environment at home. As we need to work at home until unpredictable time, we have to make sure that we are working in a proper place and support our health and performance. For instance, putting the brigher light, ergonomic chair and table.

3. Organize the schedule

4. Keep informed on the work progress.

5. Focus on the main tasks

Working from home during the pandemic is not an option or voluntary, but it is an obligation. Even though the organization hasn't set a policy in the WFH scheme, they have to create the procedure and policy immediately. In table 3 it showed that $73.3 \%$ of respondents reported that their organization hasn't ready to apply the WFH policy. Yet, they provide moral support to employees to keep focus and perform during this difficult situation. It is worth noting that even though employees are satisfied with their performance during WFH, they would not choose WFH as a choice in the future. 


\section{MANAGERIAL IMPLICATION}

Experiences during the pandemic revealed in this study give HR professionals and their organization's practical implications in designing remote work, supporting policy makers updating the policy for the future after Covid-19 Pandemic.

1. During WFH, the supervisor needs to manage employee's performance by clearly set daily or weekly goals. It is essential to reduce ambiguity and unclear expectations during work remotely with supervisors and team members.

2. Update some policy regarding permission to access the servers or data from home and applies software to monitor employee activity during work hours and non-work hours.

3. Establish an open electronic communication to stay connected with supervisors and team members. Communication should not be limited to work-related issues but also personal and social lives (they are welcome to share their struggles and anxiety).

4. Consider more flexibility to allow the employee to balance their roles in the family and at work.

5. Train the employee on the well-being and health and safety program. This knowledge can be applied when they work at home. Encourage workers to maintain their mental and physical health during WFH will help them to perform better.
6. Introducing new teleworking regulations, for instance employees are allowed to reimburse (fully or partially) the costs of internet and other telework-specific costs.

\section{CONCLUSION}

During the Covid-19 Pandemic, work from home (WFH) terminology has been using to refer to a work arrangement in which an employee accomplishes their tasks while staying at home. Although previous studies have revealed that teleworking or remote working has positive impacts on organizations and individuals, the outcomes might be distinct in the Covid-19 Pandemic situation. The results showed that during the Covid-19 Pandemic, employees gain benefits in terms of flexibility, more time with family, and time saved with less commuting. On the other hand, they also got disadvantages because of lack of engagement with supervisors and colleagues, feeling isolated, and get lower pay. Then, the main challenges are blurred boundaries between personal life and work, lack of adequate devices, and limited access to the software. The organization should pay attention to remote working or WFH schemes because this type of flexible work arrangement (FWA) might be the new norm in the future. Therefore, a suitable policy of the WFH scheme is needed for employers and employees' guides on working from home.

\section{ACKNOWLEDGEMENTS}

We gratefully thank the Maranatha Christian University for financial support. 
Aropah, V., Sarma, M., \& Sumertajaya, I.M. (2020). Factors Affecting Employee Performance during Work from Home. International Research Journal of Business Studies, 13, 2, 201-214. https://doi.org/10.21632/irjbs.13.2.201-214

Alexander, A., Smet, Aaron., \& Mysore, M. (2020). Reimagining the postpandemic workforce. McKinsey Quarterly, 7. https:// www.mckinsey.com/business-functions/organization/our-insights/reimagining-the-postpandemic-workforce

Adisa, T.A., Aiyenitaju, O., \& Adekoya, O.D. (2021). The work-family balance of British working women during the COVID-19 pandemic. Journal of Work-Applied Management, https://doi.org/10.1108/JWAM-07-2020-0036

Autor, D., Mindell, D. \& Reynolds, E. (2019). The Work of the Future: Shaping Technology and Institutions. 2019. Available online: https://workofthefuture.mit.edu/wp-content/uploads/2020/08/WorkoftheFuture_Report_Shaping_Technology_ and_Institutions.pdf

Banerjee, D., \& Rai, M. (2020). Social isolation in Covid-19: The impact of loneliness. International Journal of Social Psychiatry, 66, 525-527. https://doi.org/10.1177/0020764020922269

Eurofound. (2020). Living, working and COVID-19: First findings - April 2020. Dublin: Eurofound.

Kropf, B. M. (1999). Flexibility initiatives: Current approaches and effective strategies. Women in Management Review, 14(5), pp. 177-185.

Kniffin, K. M., Narayanan, J., Anseel, F., Antonakis, J., Ashford, S., Bakker, A. B., . . van vugt, m. (2020). COVID-19 and the Workplace: Implications, Issues, and Insights for Future Research and Action. https://doi.org/10.1037/amp0000716

Maxwell, G., Rankine, L., Bell, S., \& MacVicar, A. (2007) The incidence and impact of FWAs in smaller businesses. Employee Relations, 29, 138-161.

Perez, M., Sánchez, A., Carnicer, P., \& Jiménez, M. (2005). The differences of firm resources and the adoption of teleworking. Technovation. 25, 1476-1483. https://doi.org/10.1016/j.technovation.2005.04.002.

Shwab, K. (2016). The Fourth Industrial Revolution, 1st ed.; World Economic Forum: Geneva, Switzerland.

Society for Human Resource Management. (2015, April). SHRM Research: Flexible Work Arrangements. Retrieved from https:// www.shrm.org/hr-today/trends-and forecasting/special-reports-and-expert views/Documents/Flexible\%20Work\%20 Arrangements.pdf

Teleworking during the COVID-19 pandemic and beyond A practical guide. Geneva: International Labour Office, July 2020. ISBN 978-92-2-032405-9 (web PDF)

Wang, B., Liu, Y., Qian, J., \& Parker, S. (2020). Achieving Effective Remote Working During the COVID-19 Pandemic: A Work Design Perspective. Applied Psychology, 70, 16-59. https://doi.org/10.1111/apps.12290

Williams, S.N., Armitage C.J., Tampe, T, \& Dianes, K. (2020). Public perceptions and experiences of social distancing and social isolation during the COVID-19 pandemic: a UK-based focus group study. BMJ Open, 10. http://dx.doi.org/10.1136/ bmjopen-2020-039334 